\title{
Quá trình hình thành và phát triển đường lối đổi mới về kinh tế ở Việt Nam (1986-2015)
}

- Võ Văn Sen

- Dương Thành Thông

Trường Đại học Khoa học Xã hội và Nhân văn, ĐHQG-HCM

\section{TÓM TÁT:}

Sự sụp đổ của chế độ xã hội chủ nghĩa ở Liên Xô và các nước Xã hội Chủ nghĩa Đông Âu cuối thể kỷ 20 là sự sụp đổ của một loại mô hình chủ nghĩa xã hội không phù hợp quy luật. Ở Việt Nam, sau khi thống nhất đất nước, trước những yêu cầu đặt ra của tình hình kinh tế - xã hội của đất nước, Đảng Cộng sản Việt Nam đã đề ra đường lối lãnh đạo công cuộc đổi mới một cách toàn diện, mà trước hết là đổi mới kinh tế với nội dung trọng tâm là chuyển đổi mô hình kinh tế kế hoạch hóa tập trung, bao cấp sang nền kinh tế thị trường định hướng xã hội chủ nghĩa; đồng thời thực hiện chính sách mở cửa, hội nhập quốc tế. Cơ sỏ của đường lối đổi mói đó là một quá trình đúc kết từ thực tiễn đời sống kinh tế - xã hội của đất nước lúc bấy giờ và những bài học đắt giá từ mô hình xã hội chủ nghĩa cũng như công cuộc cải cách, cải tổ ở các nước xã hội chủ nghĩa. Bài viết này muốn phác qua quá trình hình thành và phát triển của tư duy, đường lối đổi mới kinh tế ở Việt Nam từ góc nhìn những thành công và bài học kinh nghiệm.

Từ khóa: đổi mới, kinh tế Việt Nam, Xã hội chủ nghĩa

1. Từ bài học về con đường cải cách, cải tổ ở các nước Xã hội chủ nghĩa

Sau hơn hai mươi năm chế độ xã hội chủ nghĩa ở Liên Xô và Đông Âu sụp đổ, ở Việt Nam, chế độ xã hội chủ nghĩa, con đường quá độ lên chủ nghĩa xã hội vẫn tiếp tục hoàn thiện và phát triển mạnh mẽ. Điều đó cho thấy sự sụp đổ ở Liên Xô và Đông Âu chỉ là sự sụp đổ của riêng một loại mô hình chủ nghĩa xã hội không phù hợp; sự thất bại của "perestroika" hay cải cách ở những nơi đó cũng chỉ là thất bại của loại hình cải tổ, cải cách không đúng quy luật, không phù hợp. Trên cơ sở nhạy bén tổng kết những năng động, sáng tạo của quần chúng, Đảng Cộng Sản Việt Nam đã đúc kết, hình thành và phát triển đường lối đổi mới cho cả nước với nội dung trọng tâm là chuyển đổi mô hình kinh tế kế hoạch hóa tập trung, bao cấp sang nền kinh tế thị trường định hướng xã hội chủ nghĩa; đồng thời thực hiện chính sách mở cửa, hội nhập quốc tế. Những thành tựu đạt được sau 30 năm đổi mới đã làm thay đổi căn bản và toàn diện diện mạo đất nước, đời sống nhân dân được cải thiện, vai trò và vị thế quốc tế của Việt Nam ngày càng được nâng cao... Song bên cạnh đó, đất nước vẫn đang đứng trước không ít những khó khăn thách thức, đòi hỏi những nỗ lực đổi mới mạnh mẽ hơn, quyết liệt hơn, mà trước hết là đổi mới đường lối về con đường đi lên chủ nghĩa xã hội. Bài viết này muốn phác qua quá trình hình thành và phát triển của tư duy, đường lối đổi mới kinh tế ở Việt Nam từ góc nhìn những thành công và bài học kinh nghiệm.

Nguyên nhân khách quan sâu xa cho công cuộc cải tổ ở Liên Xô, cải cách ở Trung Quốc, cũng như nhiều nước xã hội chủ nghĩa khác và đổi mới ở Việt

\section{Trang 118}


Nam là bắt nguồn từ những khó khăn, bế tắc về cả thực tiễn và lý luận về con đường xây dựng chủ nghĩa xã hội và mô hình của chủ nghĩa xã hội.

Trong sự nghiệp của mình, phần lớn các tác phẩm của Karl Marx (1818-1883) đề cập đến chủ nghĩa tư bản đều với tư cách một nhà phê bình cách mạng của chủ nghĩa tư bản. Học thuyết của ông đã thấy được chủ nghĩa tư bản với nền kinh tế thị trường tư bản chủ nghĩa chính là cỗ máy đã làm cho lực lượng sản xuất phát triển mạnh mẽ chưa từng có trước đó. Đồng thời ông cũng nhìn thấy mặt tiêu cực của nền kinh tế thị trường là sự tha hóa của lao động, sự bóc lột giá trị thặng dư của giai cấp tư sản đối với giai cấp vô sản. Và do đó, sự tích lũy tư bản càng phát triển cũng đồng thời với sự bần cùng hóa của giai cấp vô sản, làm nảy sinh những mâu thuẫn xã hội ngày càng gay gắt mà kết quả là một cách mạng xã hội sẽ bùng nổ, giai cấp vô sản sẽ thay thế vươn lên nằm quyền lực xã hội, chủ nghĩa xã hội sẽ thay thế chủ nghĩa tư bản. Tuy nhiên, chủ nghĩa Marx cũng chỉ ra rằng, sự thay thế sẽ chỉ diễn ra ở ở nơi chủ nghĩa tư bản trở thành một vật cản đối với quá trình phát triển của lực lượng sản xuất, nhưng cũng đã chuẩn bị những tiền đề cần thiết cho một hệ thống sản xuất có trình độ cao hơn nó - tức ở thời điểm đỉnh cao, chín muồi của hệ thống sản xuất tư bản chủ nghĩa". Theo đó, "giũa xã hội tu bản chủ nghĩa và xã hội cộng sản chủ nghĩa, là một thời kỳ cải biến cách mạng tù xã hội no sang xã hội kia"2. Hơn nữa, do những hạn chế lịch sử nhất định, do mô hình chủ nghĩa xã hội còn là vấn đề của vài thế kỷ sau đó, nên dù đã có những dự báo thiên tài về chủ nghĩa xã hội, Marx và Engels vẫn không thể nhìn ra vai trò của kinh tế thị trường trong chủ nghĩa xã hội. Các thế hệ cách mạng tương lai đã chậm nhận ra và khắc phục về lý luận những hạn chế này của Marx và Engels.

\footnotetext{
${ }^{1}$ János Kornai (1992), The Socialist System (Hệ thống Xã hội chủ nghĩa), NXB Princeton University, Princeton, New Jersey, tr.16-17.

${ }^{2}$ C.Mác và Ăngnghen (1993), Toàn tập, tập 18, NXB Chính trị Quốc gia, Hà Nội, tr.47.
}

Lênin (1870-1924) là người kế tục và phát triển chủ nghĩa Marx với những quan điểm cụ thể hơn về thời kỳ quá độ từ chủ nghĩa tư bản sang chủ nghĩa xã hội, đặc biệt là về mô hình kinh tế. Theo đó, Lênin chỉ rõ sự cần thiết của một cấu trúc bao gồm nhiều thành phần kinh tế đan xen giữa kinh tế nhà nước, kinh tế tập thể với kinh tế tư bản tư nhân. Về vị trí và vai trò của chủ nghĩa tư bản nhà nước trong thời kỳ quá độ ở Nga, Lênin cho rằng "Chủ nghĩa tu bản độc quyền - nhà nuớc là sự chuẩn bị vật chất đầy đủ nhất cho chủ nghĩa xã hội, là phòng chờ đi vào chủ nghĩa xã hội, là nấc thang lịch sủ, mà giũa nó với nấc thang được gọi là chủ nghĩa xã hội thì không có một nấc nào ở giữa cả”’3.Theo Lênin, một kinh tế nhiều thành phần đan xen là một đặc trưng cơ bản của bước quá độ từ chủ nghĩa tư bản lên chủ nghĩa xã hội. Quan điểm trên đây của Lenin được cụ thể hóa bằng Chinh sách kinh tế mói (Новая экономическая политика - Novaya Ekonomicheskaya Politika, НЭП -NEP) được thực hiện ở Liên Xô trong những năm 1921-1929 với những điều chỉnh nền kinh tế hướng đến việc mở rộng quan hệ hàng hoá - tiền tệ, phát triển thị trường, khôi phục và phát triển các thành phần kinh tế. Chính sách kinh tế mới đã phát huy được hiệu quả của nó khi đưa Liên Xô thoát khỏi những khủng hoảng chính trị - kinh tế - xã hội. Có thể nói Lenin đã phần nào nhìn thấy vai trò của kinh tế thị trường trên con đường xây dựng chủ nghĩa xã hội và trong chủ nghĩa xã hội. Lênin đã nhìn thấy những hạn chế của Marx và NEP là một nỗ lực đổi mới về lý luận.Thế nhưng, điều đáng tiếc của lịch sử là Lenin đã sớm ra đi sau khi hiểu ra điều này!

Stalin (1878-1953) đã không hiểu gì về những hạn chế của Marx, Engels và cả bản chất NEP của Lênin. Nền kinh tế Liên Xô dần xa rời những quan điểm kinh tế của Lenin đã đề ra trong Chính sách kinh tế mới. "Mô hình Satlin" được áp dụng ở Liên Xô từ những năm 1930 và được hoàn chỉnh về lý luận với sự ra đời của tác phẩm "Nhũng vấn đề kinh

${ }^{3}$ Lênin (1978), Toàn tập (tập 36), NXB Tiến bộ, Moskva, tr.371. 
tế của chủ nghĩa xã hội ở Liên Xô" của Stalin xuất bản năm $1952^{4}$. Bên cạnh khẳng định tính ưu việt của chủ nghĩa xã hội và sự sụp đổ mang tính tất yếu của chủ nghĩa tư bản, tác phẩm cũng xây dựng một mô hình kinh tế của chủ nghĩa xã hội. Mô hình đó cho rằng cơ chế thị trường là một cơ chế hoạt động kém, cần phải được thay bằng cơ chế kế hoạch hóa có ý thức; do đó, cần phải xóa bỏ hệ thống sở hữu tư nhân để chấm dứt cách điều phối sản xuất thị trường một cách mù quáng, thay thế nó bằng kế hoạch có ý thức. "Tu tương này ảnh huởng đến toàn bộ nhũng công trình phu thuộc vào các Đảng Cộng sản gắn với Liên Xô và một cách gián tiếp đến toàn bộ tu tương gắn với các tổ chức công nhân hay với các phong trào giải phóng dân tộc"5. Và quả thực, những quan điểm này nhanh chóng trở thành những nguyên lý chung trong thiết chế kinh tế của các nước thuộc hệ thống xã hội chủ nghĩa'.

Từ khá sớm, mô hình Stalin đã bị cho là mắc phải những sai lầm nghiêm trọng, hoặc từ những người Trosky hoặc các nhóm cách mạng khác. Ngay trong nội bộ các nước xã hội chủ nghĩa cũng bước đầu nảy sinh những bất đồng về các quan điểm mô hình. Ở Trung Quốc, ngay từ năm 1937, những tác phẩm Bàn về thực tiễn, Bàn về mâu thuẫn (1937) của Mao Trạch Đông (1893-1976) đã dẫn đến những rạn nứt về tư tưởng giữa hai nước, dẫn đến sự "đoạn tuyệt" của Trung Quốc với Liên Xô từ

\footnotetext{
${ }^{4}$ Những quan điểm của "mô hình Stalin" bị ảnh hưởng lớn từ tư tưởng kinh tế của Préobrajensky qua tác phẩm $A B C$ của Chủ nghĩa cộng sản viết chung với Boukharine, xuất bản ở Liên Xô năm 1919. Năm 1954, trên cơ sở tác phẩm Nhũng vấn đề kinh tế của chủ nghĩa xã hội ở Liên Xô, bộ "Sách giáo khoa Kinh tế chính trị" được in và phát hành rộng rãi ở Liên Xô và nhiều nước xã hội chủ nghĩa khác, trở thành tác phẩm "gối đầu giường" của nhiều mô hình kinh tế xã hội chủ nghĩa theo khuôn mẫu kiểu Liên Xô thời Stalin.

${ }^{5}$ Michel Beaud - Gilles Dostaler (2008), Tu tuởng kinh tế kể tù Keynes, NXB Tri thức, Hà Nội, tr.167.

${ }^{6}$ Hội nghị các Đảng Cộng sản và Công nhân quốc tế lần thứ nhất lại Moskva năm 1957 đã chỉ ra những nguyên lý chung của thiết chế kinh tế xã hội chủ nghĩa là:

- Thủ tiêu chế độ sở hữu tư bản chủ nghĩa và xây dựng chế độ sở hữu công cộng;

- Cải tạo nông nghiệp theo chủ nghĩa xã hội;

- Phát triển kinh tế có kế hoạch.

(Theo Cuoong lĩnh của chúng ta (1957), NXB Sự thật, Hà Nội, tr.24)
}

\section{Trang 120}

1960. Ở các nước xã hội chủ nghĩa khác, những bất cập của nền kinh tế kế hoạch hóa, tập trung quan liêu, bao cấp dẫn đến nhiều đề nghị cải cách, với I.Birman, V.Nemchinov, E.Liberman ở Liên Xô, W.Brus ở Ba Lan, O.Sik tại Tiệp Khắc, J.Kornai ở Hungari... ${ }^{7}$.

Năm 1973, cuộc khủng hoảng dầu mỏ nghiêm trọng chưa từng có bùng nổ ở Trung Đông rồi nhanh chóng kéo theo những khủng hoảng chính trị, kinh tế, tài chính, tiền tệ... trên quy mô toàn thế giới. Cuộc khủng hoảng đặt ra cho nhân loại những vấn đề bức thiết phải đối mặt như: sự bùng nổ dân số và hiểm hoạ vơi cạn dần tài nguyên thiên nhiên; yêu cầu đổi mới, thích nghi mô hình kinh tế - chính trị - xã hội trước khủng hoảng... Những hệ quả to lớn của cuộc khủng hoảng là điều đã được nhận thấy, nhưng cùng với đó, thế giới có thêm một nhân tố trực tiếp thúc đẩy cho sự khởi đầu giai đoạn thứ hai của Cuộc cách mạng khoa hoc - kỹ thuật hiện đại với đặc điểm là sự phát triển của khoa học kỹ thuật theo chiều sâu thay vì chiều rộng, khoa học đã trở thành một lực lượng sản xuất trực tiếp nhằm hướng tới đáp ứng những đòi hòi mới về công cụ sản xuất, nguyên vật liệu, năng lượng... ${ }^{8}$. Sự phát triển của khoa học - kỹ thuật cũng đồng thời thúc đẩy mạnh mẽ xu hướng toàn cầu hóa, tăng cường giao lưu và hợp tác quốc tế. Trong quan hệ quốc tế, xu hướng hợp tác, cạnh tranh dần dần nổi trội hơn xu hướng đối đầu và xung đột. Quá trình đó đặt ra yêu cầu một cách cấp thiết đối với mọi quốc gia: đổi mới để thích ứng và kịp thời nắm bắt thời cơ, tránh để tụt hậu.

\footnotetext{
${ }^{7}$ Michel Beaud - Gilles Dostaler (2008), Sđd, tr.167.

Cần phải nói thêm, một trong những sai lầm của mô hình Stalin trong thời kỳ này là đồng nhất kinh tế thị trường với chủ nghĩa tu bản, còn chủ nghĩa xã hội thì không, bởi "sụ phân cách giũa thi truờng và nhà nuớc là một điều không xảy ra, nó không chi không có thực vì chura bao giò có thị truờng không dính líu gì đến nhà nuoớc - mà còn vì thế lực tu bản và thế lực nhà nước không hề là hai thực thể đối kháng" ( Xem: Ulrike Herrmann (2014), Tâu Âu trong tiến trình phát triển kinh tế. Con đường đura thế giới đến thịnh vurợng: lịch sủ tiến trình xã hội, lịch sủ tiền tệ và nhũng cuộc khủng hoảng, NXB Tri thức, Hà Nội, tr.158).

${ }^{8}$ Giai đoạn 2 của Cách mạng khoa học - kỹ thuật hiện đại còn gọi là Cách mạng khoa học - công nghệ.
} 
Tình hình đó đặt các quốc gia trước đồng thời hai ngưỡng cửa: những thời cơ để tăng tốc và những nguy cơ khủng mới. Liên Xô và các nước Xã hội Chủ nghĩa Đông Âu trong những năm 1950-1975 đã đẩy mạnh quá trình công nghiệp hóa, đạt được những thành tựu kinh tế - xã hội to lớn. Tuy nhiên, dưới tác động của cuộc khủng hoảng năng lượng năm 1973, từ giữa thập niên 1970 của thế kỷ XX nhịp độ tăng trưởng kinh tế của Liên Xô và các nước Xã hội chủ nghĩa Đông Âu suy giảm rõ rệt. Tại Liên Xô, những điều chỉnh chậm chạp của nhà nước cùng với những thiếu sót, sai lầm trong mô hình kinh tế - chính trị - xã hội vốn tích tụ từ trước đó khiến những nỗ lực cải thiện tình hình không thu được hiệu quả. Tại các nước Đông Âu, nhiều nỗ lực phát triển kinh tế - xã hội được tiến hành song không mấy hiệu quả khi mà những mâu thuẫn và xung đột tích tụ đã không thể điều hòa được.

Tháng 3-1985, Liên Xô tiến hành công cuộc "Cải tổ" (Perestroika: Перестройка) do Mikhail Sergeyevich Gorbachev (1931- ) khởi xướng. Mục tiêu đặt ra là đổi mới mọi mặt đời sống kinh tế - xã hội, khắc phục những sai lầm, thiếu sót, đưa đất nước thoát khỏi tình trạng khủng hoảng, trì trệ và xây dựng chủ nghĩa xã hội đúng với bản chất của nó. Tuy nhiên, sau 6 năm cải tổ, tình hình kinh tế xã hội Liên Xô không có nhiều cải tiến, những sai lầm không được khắc phục có xu hướng trầm trọng thêm, những nỗ lực cải tổ về cả kinh tế lẫn chính trị rơi vào bế tắc... Tháng 12/1991, Liên bang Xô Viết tuyên bố giải tán, đánh dấu sự sụp đổ của chế độ xã hội chủ nghĩa ở Liên Xô sau 74 năm tồn tại.

Tại các nước Đông Âu, cuộc khủng hoảng toàn chính trị - kinh tế toàn diện diễn ra đầu tiên ở $\mathrm{Ba}$ Lan năm 1988 rồi nhanh chóng lan sang các nước khác. Tháng 11/1989, bức tường Berlin - biểu tượng của sự chia cắt Đông Đức - Tây Đức - bị dỡ bỏ. Ngày 28/6/1991, Hội đồng tương trợ kinh tế SEV tuyên bố giải thể; ngày 1/7/1991, Khối Hiệp ước Warszawa chấm dứt hoạt động, đánh dấu sự tan rã của hệ thống xã hội chủ nghĩa thế giới.
Trong khi đó ở Trung Quốc, sau khi Mao Trạch Đông mất và Đại cách mạng văn hóa vô sản (19661976) kết thúc, Đặng Tiểu Bình (1904-1997) và tập thể lãnh đạo mới của Trung Quốc bắt đầu công cuộc cải cách kinh tế và chuyển đổi theo hướng kinh tế hỗn hợp định hướng thị trường dưới sự lãnh đạo của Đảng Cộng sản (tháng 12/1978). Sau 10 năm tiến hành cải cách, nền kinh tế - chính trị - xã hội Trung Quốc đã có nhiều khởi sắc, bước đầu thoát khỏi khủng hoảng, mở ra một thời kỳ phát triển mới cho đất nước này.

\section{2. Đến quá trình hình thành và phát triển của con đường đổi mới ở Việt Nam}

Sự thất bại trong công cuộc cải tổ ở Liên Xô và các nước Đông Âu và thành công của công cuộc cải cách ở Trung Quốc đã có tác động mạnh mẽ đến nước ta. Tình hình đó chứng minh rằng sự sụp đổ của chủ nghĩa xã hội ở Liên Xô và các nước Đông Âu không phải là sự khủng hoảng mang tính bản chất của chủ nghĩa xã hội nói chung mà chỉ là sự thất bại của một mô hình xã hội chủ nghĩa cụ thể không phù hợp; nhiệm vụ của Đảng Cộng sản tại các nước là phải đẩy nhanh tiến trình đổi mới, cải cách, tìm ra mô hình kinh tế - xã hội phù hợp với thực tiễn mỗi nước. Hơn nữa, những kinh nghiệm thành công của các nước công nghiệp mới (NIC) ở Đông Á cũng đã cung cấp cho Việt Nam những bài học sâu sắc về con đường công nghiệp hóa, hiện đại hóa, nhất là những bài học về hội nhập quốc tế, hướng về xuất khẩu, phát huy cao nhất nội lực của đất nước,...

Thế nhưng đối với công cuộc đổi mới ở Việt Nam thì nguyên nhân chủ quan trong nước mới là nhân tố quyết định nhất.

Do những hạn chế về lý luận, ngay sau khi thống nhất đất nước Đảng ta đã không nhìn nhận chính xác hoàn toàn "điểm xuất phát" mà từ đó cả nước quá độ lên chủ nghĩa xã hội, cũng như vai trò của kinh tế thị trường trong mô hình chủ nghĩa xã hội ở Việt Nam; không thấy được những tích cực khách quan của sự phát triển của kinh tế TBCN ở miền Nam trong điều kiện chiến tranh, cũng như 
tính không thích hợp của cơ chế tập trung bao cấp đã tồn tại ở miền Bắc thời chiến tranh đối với quá trình xây dựng kinh tế trong hòa bình và thống nhất đất nước.

Hội nghị Ban chấp hành Trung ương Đảng lần thứ 24 (khóa III) từ ngày 24 đến ngày 29-9/1975 thống nhất chủ trương cải tạo, xóa bỏ những thành phần kinh tế phi xã hội chủ nghĩa ở miền Nam, đẩy nhanh công cuộc xây dựng nền sản xuất lớn xã hội chủ nghĩa theo mô hình kinh tế ở miền Bắc, với những nội dung cụ thể như: "trung thu toàn bộ các co sở kinh doanh thuoong nghiệp, vận tải, nhà cưa của tu sản mại bản"; "đẩy mạn xã hội chủ nghĩa và phát triển kinh tế theo huớng cả nuoóc cùng tiến lên sản xuất lớn xã hội chủ nghĩa" 9; "phải xóa bỏ tu sản mại bản bằng cách quốc hũu hóa co sở kinh tế của họ, biến thành sở hũu toàn dân do nhà nuoóc quản lȳ", "đối với kinh tế tu sản dân tộc, thực hiện cải tạo xã hội chủ nghĩa bằng hình thức công tu hơp doanh" ${ }^{\prime 10}$.. Tiếp đó, Đại hội Đảng toàn quốc lần thứ IV tháng 9/1976, tiếp tục khẳng định chủ trương xây dựng nền sản xuất lớn xã hội chủ nghĩa bằng ba cuộc cách mạng lớn: cách mạng quan hệ sản xuất, cách mạng khoa học kỹ thuật và cách mạng văn hóa tư tưởng.

Triển khai thực hiện đường lối của Đại hội Đảng toàn quốc lần thứ IV, những năm 1976-1980, bên cạnh những thành tựu căn bản đạt được, đất nước đứng trước những thử thách cam go: Mỹ áp dụng chính sách cấm vận đối với Việt Nam; cuộc chiến tranh biên giới Tây Nam với Pol Pot và chiến tranh biên giới phía Bắc với Trung Quốc trong những năm 1977-1979; các khoản viện trợ từ các nước xã hội chủ nghĩa bị suy giảm... Những khó khăn từ tình hình bên ngoài cộng với sai lầm và bất cập trong chính sách kinh tế cũng như quản lý điều hành ${ }^{11}$ đã dẫn đến sự mất cân đối lớn trong nền kinh

${ }^{9}$ Đảng Cộng sản Việt Nam (2004), Văn kiện Đảng toàn tập (tập 36), NXB Chính trị Quốc gia, Hà Nội, tr.348-349.

${ }^{10}$ Đảng Cộng sản Việt Nam (2004), Văn kiện Đảng toàn tập (tập 36), tr.408.

${ }^{11}$ Như việc phủ nhận, dẫn đến chủ trương xóa bỏ hoàn toàn thành phần kinh tế tư nhân; xem nhẹ vai trò của cơ chế thị trường tế: kinh tế quốc doanh và tập thể không phát huy được hiệu quả, luôn trong tình trạng thua lỗ trong khi kinh tế tư nhân, cá thể bị ngăn cấm; sản xuất tăng trưởng chậm, năng xuất lao động thấp, đời sống nhân dân gặp nhiều khó khăn...

Cho đến những năm cuối của kế hoạch 5 năm 1976-1980, trước những khủng hoảng, ách tắc của nền kinh tế, nhiều vấn đề, câu hỏi được đặt ra ở cả Trung ương lẫn cơ sở. Trước tình hình đó, từ cuối năm 1978, Trung ương Đảng đã có nhiều đợt điều tra, tìm hiểu về thực trạng kinh tế - xã hội ở các địa phương. Trên cơ đó, ngày 18/5/1979, Bộ Chính trị ban hành Thông báo số $10-\mathrm{TB} / \mathrm{TU}$ về việc khẩn cấp điều chỉnh một số chỉ tiêu và biện pháp kinh tế trong hai năm cuối kế hoạch 5 năm 1976-1980, trong đó nhấn mạnh đến phát triển sản xuất, chú trọng thực thi các biện pháp kinh tế gắn với tình hình thực tế kinh tế - xã hội ở địa phương... Tiếp đó, tháng 8/1979, Ban Chấp hành Trung ương họp Hội nghị toàn quốc lần thứ 6 , nhìn nhận những sai lầm, thiếu sót và "xóa bỏ ngay nhũng chính sách, chế độ bất hợp lý, gây trở ngại cho sản xuất, khuyết khích việc phát triển sản xuất hàng tiêu dùng và phát triển công nghiệp ở địa phuong, mở rộng quyền chủ động hợp lý của các ngành, các địa phuoong và các cơ sở (kể cả quốc doanh, tập thể, cá thể) trong sản xuất, kinh doanh nhằm làm cho sản xuất "bung ra" để có nhiều hàng hóa cho xã hội. Kết hơp đưng đắn ba loai lợ ích: lợi ích toàn xã hộ, lợi ích tập thể và lợi ích của ngườ sản xuất"12.

Những tư tưởng mang tính "cởi trói” trên đây của Đảng đã có tác động tích cực, góp phần đẩy nhanh những hiện tượng "phá rào" trong sản xuất, kinh doanh, vốn đã manh nha tại nhiều địa phương.

Trong công nghiệp và giao thông vận tải, những đột phá mạnh mẽ của xí nghiệp Dệt Thành Công (TP. Hồ Chí Minh), nhà máy Dệt lụa Nam Định,

và những quy luật của nó, dẫn đến việc áp đặt các biện pháp hành chính trong quản lý điều hành nền kinh tế; chủ quan duy ý chí, áp đặt một cách rập khuôn, máy móc mô hình kinh tế không phù hợp vào nền kinh tế đất nước trong hoàn cảnh mới v.v...

${ }^{12}$ Đảng Cộng sản Việt Nam (2004), Văn kiện Đảng toàn tập (tập 40), tr. 265 .

\section{Trang 122}


nhà máy Thuốc lá Vĩnh Hội (TP. Hồ Chí Minh), xí nghiệp Đánh cá Côn Đảo - Vũng Tàu, công ty Xuất khẩu Thủy sản Việt Nam (SEAPRODEX) hay công ty Xe khách Miền Đông (TP. Hồ Chí Minh)... là những trường hợp tiêu biểu ${ }^{13}$.

Trong nông nghiệp, những mô hình làm ăn theo hình thức "khoán" ở Vĩnh Phúc, Hải Phòng, Nông trường Sông Hậu hay chính sách "Tam nông” ở An Giang... là những điển hình đột phá14.

Trong cơ chế mua bán - giá cả, những cách làm "vượt đèn đỏ” ở công ty Lương thực TP. Hồ Chí Minh, thu mua giá lúa vượt khung ở An Giang, chuyện bỏ tem phiếu áp dụng cơ chế một giá ở Long An hay mô hình Kho bạc Nhà nước ở An Giang... thực sự là những trường hợp "bung ra"15.

Trong hoạt động ngoại thương, trường hợp "lén cởi trói” tại công ty Ngoại thương TP. Hồ Chí Minh (IMEX SAIGON) cùng với sự ra đời của một loạt các công ty xuất nhập khẩu như DIREXIMCO, CHOLIMEX, PHICONIMEX, PHARIMEX..., hay những ý tưởng đột phá trong lĩnh vực thị trường tài chính đối ngoại của VIETCOMBANK... là những điểm sáng trong nỗ lực tìm tòi, cởi trói trước cơ chế16.

Tất cả những hiện tượng "phá rào" đó đã có tác động mạnh mẽ đến những thay đổi trong tư duy nhận thức của những nhà lãnh đạo đất nước, là cơ sở thực tiễn của những điều chỉnh, thay đổi về cơ chế, chính sách của Đảng và Nhà nước.

Đối với các ngành công nghiệp và giao thông vận tải, năm 1981, với Quyết định số 25-CP ban hành ngày 21/1/1981, Chính phủ đã cho phép áp dụng chế độ ba kế hoạch đối với các xí nghiệp, công ty vận tải. Trong nông nghiệp, ngày 13/1/1981, Ban Bí thư ra Chỉ thị 100-CT, cho phép áp dụng chế độ khoán trong nền nông nghiệp cả nước. Trong hoạt động xuất nhập khẩu, tháng 2/1980, Chính phủ ra Nghị quyết 40-CP, cho phép

\footnotetext{
13 Xem thêm Đặng Phong (2009), "Phá rào” trong kinh tế vào đêm trước đổi mới, NXB Tri thức, Hà Nội, tr.57-154.

${ }^{14}$ Xem thêm Đặng Phong (2009), Sđd, tr.163-274.

15 Xem thêm Đăng Phong (2009), Sđd, tr.301-384.

${ }^{16}$ Xem thêm Đặng Phong (2009), Sđd, tr.429-472.
}

thực hiện xuất nhập khẩu địa phương. Trong cơ chế mua bán - giá cả, ngày 23/6/1980, Bộ Chính trị ban hành Nghị quyết số 26-NQ/TU về cải tiến công tác giá lưu thông, điều chỉnh giá để khuyến khích sản xuất, cải tiến hệ thống thu mua, cho phép các liên hợp xí nghiệp, công ty mua theo giá thỏa thuận một số nguyên liệu, vật tư mà Nhà nước không thể cung ứng... Trong năm 1981, theo tinh thần của Chỉ thị số 109-CT của Bộ Chính trị về chủ trương tiếp tục đẩy mạnh thực hiện Nghị quyết số 26 về cải tiến công tác phân phối lưu thông, Chính phủ liên tiếp ban hành nhiều chính sách mới điều chỉnh giá, lương (Cuộc cải cách giá lần thứ nhất).

Trên cơ sở những hiệu ứng tích cực của cuộc cải cách giá lần thứ nhất, ngày 17/6/1985, Ban chấp hành Trung ương Đảng khóa $\mathrm{V}$ họp lần thứ 8 đã ra Nghị quyết về "giá - lương - tiền" chủ trương áp dụng trong cả nước, xếp lại lương mới cho tất cả các đối tượng hưởng lương, khẳng định "phải dút khoát xóa bỏ co chế tập trung quan liêu bao cấp, thực hiện đưng chế độ tập trung dân chủ, hạch toán kinh tế và kinh doanh xã hội chủ nghĩa". Thực tế thực hiện cuộc cải cách giá lần thứ hai đã không thu được kết quả như mong đợi, thậm chí gây những bất ổn cho nền kinh tế do tình trạng lạm phát tăng nhanh. Tuy nhiên, nhìn một cách biện chứng, chính những khó khăn, thất bại khi triển khai Nghị quyết về "giá - lương - tiền" cho thấy phải đổi mới toàn diện, triệt để cơ chế kinh tế, không thể tiếp tục duy trì cơ chế quan liêu bao cấp ${ }^{17}$.

Đại hội Đảng toàn quốc lần thứ VI $(12 / 1986)$ đã thể hiện rõ tư duy đổi mới với tinh thần "chỉ có đổi mới thì mới thấy đúng và thấy hết sự thật, thây những nhân tố mới để phát huy, những sai lầm để sửa chữa"18, do đó phải "nhìn thẳng vào sự thật, tôn trọng sự thật, nói đúng sự thật"19. Đại hội xác định, trong nhiều năm qua, Đảng đã mắc phải "những sai lầm nghiêm trọng và kéo dài về chủ trương chính

\footnotetext{
${ }^{17}$ Xem thêm Đặng Phong (2009), Sđd, tr.319.

${ }^{18}$ Diễn văn khai mạc do đồng chí Nguyễn Văn Linh đọc tại Đại hội VI ngày 15-12-1986.

${ }^{19}$ Báo cáo chính trị tại Đại hội Đảng toàn quốc lần thứ VI: Văn kiện Đảng toàn tập, tập 47, tr.345
} 
sách lớn"20. Một trong những nguyên nhân quan trọng được chỉ ra là "do chưa nhận thức đầy đủ rằng, thời kỳ quá độ lên chủ nghĩa xã hội là một quá trình lịch sử tương đối dài, phải trải qua nhiều chặng đường và do tư tưởng chỉ đạo chủ quan, nóng vội, muốn bỏ qua những bước đi cần thiết..."21. Trên cơ sở đó, Đại hội chỉ ra sự cần thiết không thể thay thế của các thành phần kinh tế trong một nền kinh tế thống nhất, phải "sử dụng mọi khả năng của các thành phần kinh tế khác trong sự liên kết chặt chẽ theo nguyên tắc bảo đảm phát triển sản xuất, nâng cao hiệu quả kinh tế và tăng thu nhập cho người lao động" 22 ...

Cụ thể hóa những tư duy đổi mới trên, trong "phương hướng, mục tiêu phát triển kinh tế xã hội 5 năm 1986-1990”, nêu lên mục tiêu ba chương trình kinh tế lớn: lương thực thực phẩm, hàng tiêu dùng và hàng xuất khẩu. Có thể nói, Đại hội Đảng lần thứ VI năm 1986 đánh dấu bước chuyển quan trọng trong định hướng xây dựng phát triển đất nước trên tinh thần đổi mới một cách toàn diện và sâu sắc, trước hết là đổi mới trong tư duy kinh tế; đả phá những quan điểm cũ kỹ, bảo thủ, mở đường cho những tư duy tiến bộ, mới mẻ. Và do đó, những hiện tượng "phá rào" trong những năm trước đó không những đặt ra yêu cầu cấp thiết cho công cuộc đổi mới mà còn là cơ sở thực tiễn để kiểm chứng, là những hạt giống đầu tiên cho quá trình phai phá những ý tưởng, cách làm mới trong chặng đường đổi mới sắp tới. Từ đây, "sau hơn một thập $k y ́, y ́$ tuoơng phát triển bằng cách huy động toàn diện Đảng và Nhà nước đã nhường chố cho ý tường cho rằng chức năng chính của Nhà nuoóc là tạo ra co sỏ ha tầng vật chất xã hội và môi truò̀ng chính sách ổn định cần thiết cho sụ phát triển công bằng, dựa trên

${ }^{20}$ Báo cáo chính trị tại Đại hội Đảng toàn quốc lần thứ VI: Văn kiện Đảng toàn tập, tập 47, tr.360.

${ }^{21}$ Báo cáo chính trị tại Đại hội Đảng toàn quốc lần thứ VI: Văn kiện Đảng toàn tập, tập 47, tr.353-354.

${ }^{22}$ Báo cáo chính trị tại Đại hội Đảng toàn quốc lần thứ VI: Văn kiện Đảng toàn tập, tập 47, tr.379-380. co sơ thị trường"23. Như vậy, sau một quá trình tìm kiếm, thử nghiệm, đến Đại hội VI Đảng ta đã nắm bắt được chính xác cái “chìa khóa” quyết định nhất đề đổi mới nền kinh tế nước ta chính là đổi mới cơ chế kinh tế, chấm dứt cơ chế tập trung quan liêu bao cấp, chuyển sang cơ chế kinh tế thị trường.

Tư duy đổi mới đã có, nhưng những năm sau đó, nhất là giai đoạn 1987-1988 là những năm áp dụng đường lối đổi mới vào thực tiễn một cách khó khăn do tác động bởi những hệ lụy của quá khứ bao cấp lẫn những vấn đề mới đặt ra trong bối cảnh tình hình trong và ngoài nước có nhiều chuyển biến phức tạp. Đây cũng là giai đoạn chứng kiến những điều chỉnh hợp lý, cẩn trọng, hiệu quả trong việc áp dụng dụng các chính sách kinh tế mới.

Từ ngày 11/3/1987, Nhà nước ban hành quy định bãi bỏ các trạm kiểm soát trên tất cả các tuyến giao thông trong nước, tạo điều kiện cơ bản cho thúc đẩy lưu thông hàng hóa giữa các địa phương.

Ngày 14/11/1987, Hội đồng Bộ trưởng ban hành Quyết định số 217-HĐBT về việc giao quyền tự chủ cho các xí nghiệp quốc doanh, xóa bỏ hệ thống chỉ tiêu kinh tế, chỉ còn hai chỉ tiêu là giá trị sản lượng và khoản nộp ngân sách. Với Quyết định này, Nhà nước tiến tới xóa bỏ phần lớn các chỉ tiêu kinh tế mang tính áp đặt, giao quyền tự chủ lớn hơn cho các xí nghiệp quốc doanh, tạo điều kiện để đẩy mạnh sản xuất, tăng năng xuất lao động trên cơ sở thực tế hoạt động tại xí nghiệp.

Ngày 9/3/1988, Hội đồng Bộ trưởng ban hành Nghị định số 27-HĐBT về kinh tế tư doanh và và Nghị định số 29-HĐBT về kinh tế gia đình, cho phép phục hồi lại thành phần kinh tế tư nhân. Các Nghị định này không những tháo gỡ những ách tắc trong sản xuất kinh doanh, phát huy tối đa các nguồn nội lực vào phát triển kinh tế, mà còn thể hiện rõ một bước tiến lớn trong việc cụ thể hóa quan điểm thừa nhận một nền kinh tế có nhiều thành phần.

\footnotetext{
${ }^{23}$ Börje Ljunggren (Chủ biên, 1994), Nhũng thách thức trên con đuoòng cải cách ở Đông Dưong, NXB Chính trị Quốc gia, Hà Nội. tr.548.
}

\section{Trang 124}


Ngày 5/4/1988, Bộ Chính trị ban hành Nghị quyết $10 / \mathrm{NQ}$ về đổi mới quản lý kinh tế trong nông nghiệp, tiếp tục cải tiến chế độ khoán sản xuất nông nghiệp (hay còn gọi là Khoán 10). Nghị quyết nêu rõ: "Công nhận sư tồn tại lâu dài và tác động tích cưc của kinh tế cá thể tu nhân trong quá trình đi lên chủ nghĩa xã hộ, thùra nhận tu cách pháp nhân, đảm bảo bình đẳng về quyền lợi và nghĩa vu truócc pháp luật, bảo hộ quyền làm ăn chinh đáng và thu nhập hợp pháp của các hộ cá thể tu nhân"24.

Cho đến năm 1990, "nền kinh tế Việt Nam về nhũng phuoong diện quan trọng nhất có thể được xem nhu một nền kinh tế thị truờng - dù rằng với nhũng thị truờng kém phát triển hoặc không tồn tại đối với đất đai, lao động và vốn. Sư chuyển đổi đã hoàn tất. Hầu hết các giao dịch đều dựa trên co sở trao đổi tư nguyện và cùng có lợi. Điều này hoàn toàn khác với nhũng chỉ thị bắt buộc của hệ thống kế hoạch hóa tập trung" "25. Những chủ trương đổi mới, chuyển hướng nền kinh tế tiếp tục được khẳng định và đẩy mạnh thực hiện trong các kỳ Đại hội Đảng toàn quốc kế tiếp. Đại hội VII (1991) và Đại hội VIII (1996) đã khẳng định sự tồn tại và định hướng phát triển của nền kinh tế Việt Nam theo cơ chế thị trường. Đại hội IX (2001) và Đại hội X (2006) tiếp tục khẳng định phát triển nền kinh tế thị trường định hướng xã hội chủ nghĩa, mở rộng và chủ động hội nhập quốc tế sâu rộng. Đại hội XI (2010) quyết tâm đẩy mạnh toàn diện công cuộc đổi mới, tạo nền tảng để đến năm 2020 nước ta cơ bản trờ thành nước công nghiệp theo hướng hiện đại.

Thực hiện chủ trương phát triển kinh tế nhiều thành phần, từ năm 1989 trở đi, khu vực kinh tế nhà nước đã có nhiều nỗ lực cải tiến, cải tổ, để cải thiện năng lực cạnh tranh với các thành phần kinh tế khác, đóng vai trò là thành phần giữ vai trò chủ đạo của đất nước theo định hướng của Đảng. Bên cạnh đó, với tính chất năng động vốn có, thành phần kinh

${ }^{24}$ Đảng Cộng sản Việt Nam (2004), Văn kiện Đảng toàn tập (tập 49), tr.115-116.

${ }^{25}$ Adam Fforde - Stefan de Vylder (1997), Tù kế hoạch đến thị truờng: sư chuyển đổi kinh tế ở Việt Nam, NXB Chính trị Quốc gia, Hà Nội, tr.29. tế tư nhân đã trở thành động lực của nền kinh tế và đóng góp ngày càng nhiều hơn cho nền kinh tế đất nước. Đây có thể được xem là chủ trương mang tính đột phá quan trọng nhất, dẫn đến thành công của công cuộc đổi mới, vì nói theo J. Kornai: "Không thể xây 'Bức tuờng Berlin' giũa khu vưc nhà nuớc và khu vưc tu nhân. Có nhiều loại quan hệ giũa chúng. Một phần là các quan hệ lành mạnh phải ủng hộ. Một phần khác là các quan hệ tai hại cần phải đứng lên chống lại chúng"26.

Với chủ trương xây dựng một nền kinh tế thị trường có sự quản lý của nhà nước theo định hướng xã hội chủ nghĩa, Nhà nước đã sử dụng ngày càng có hiệu quả các công cụ điều tiết vĩ mô nền kinh tế như hoàn thiện hệ thống pháp lý27, chính sách tài chính tiền tệ, hoạch định kế hoạch phát triển của nền kinh tế, cải thiện hệ thống phân phối lưu thông, từng bước tự do hóa thương mại... Những bước đi đó, ngay từ đầu, rõ ràng là hướng tới mục tiêu "xóa bỏ quan liêu bao cấp không chỉ với lĩnh vục đời sống mà còn với lĩnh vực sản xuất, phân phối nguồn lục, trao quyền tư chủ cho xí nghiệp quốc doanh hoạch toán kinh doanh, khắc phuc tình trạng "lãi giả - lỗ thật”. Xóa bỏ ngăn sông cấm chợ với thị truờng trong nuớc và buớc đầu với thị truờng ngoài nước" 28 .

Cùng với những biện pháp thúc đẩy sản xuất, trao đổi hàng hóa trong nước, từ khi đổi mới đến nay, Việt Nam đã chủ động hội nhập khu vục và quốc tế theo hướng đa phương hóa, đa dạng hóa các quan hệ đối ngoại, chú trọng hơn đến việc huy động các nguồn lực từ bên ngoại vào công cuộc phát triển đất nước. Quan hệ với các tổ chức tài chính quyền tế như IMF, WB đã trở lại bình thường; cam kết

\footnotetext{
${ }^{26}$ Kornai János (2007), Con đường dẫn tới nền kinh tế tư do, NXB Tri thức, Hà Nội, tr.86.

${ }^{27}$ Đáng chú ý là việc sửa đổi Hiến pháp năm 1992, ban hành các luật Đầu tu của nước ngoài (sau là Luật Đầu tu), luật Thuoong mai, luật Ngân hàng và các Tổ chức tín dung, luật Ngân sách nhà nước, luật Doanh nghiệp, các đạo luật về Thuế...

${ }^{28}$ Đào Xuân Sâm - Vũ Quốc Tuấn (Chủ biên, 2008), Renovation in Vietnam: Recollection and Contemplation, NXB Tri thức, Hà Nội (Dẫn theo Phạm Minh Chính - Vương Quân Hoàng, (2009), Kinh tế Việt Nam thăng trầm và đột phá, NXB Chính trị Quốc gia, Hà Nội, tr.95).
} 
hợp tác và mở cửa thương mại với Trung Quốc, Mỹ, ASEAN, EU, Nhật Bản...; trở thành thành viên chính thức và có nhiều hoạt động tích cực trong các tổ chức quốc tế đa phương, các diễn đàn quốc tế như Liên hiệp quốc, WTO, APEC, ASEM...

\section{Thay lời kết}

Trải qua 30 năm tiến hành công cuộc đổi mới, nước ta đã bước ra khỏi khủng hoảng, nền kinh tế có bước tăng trưởng mạnh, đưa nước ta thoát khỏi nhóm nước có thu nhập thấp, hội nhập vào khối quốc gia có thu nhập trung bình, đời sống nhân dân được cải thiện đáng kể, vai trò và vị thế trường quốc tế được nâng cao... ${ }^{29}$

Thực tiễn gần 30 đổi mới ở nước ta ngoài ý nghĩa làm thay đổi diện mạo đất nước, đưa đất nước thoát khỏi khủng hoảng, từng bước hiện đại hóa, còn mang nhiều ý nghĩa và bài học lịch sử sâu sắc.

Thứ nhất, bài học về việc vận dụng một cách đúng đắn, sáng tạo và linh hoạt những nguyên lý của chủ nghĩa Marx - Lenin vào thực tiễn xây dựng và phát triển đất nước trong mỗi thời kỳ, giai đoạn lịch sử. Kiên định đi theo chủ nghĩa Marx - Lenin,

\footnotetext{
${ }^{29}$ Về phát triển kinh tế:

- Giai đoạn 1986 - 1990: GDP tăng 4,4\%/năm; tổng giá trị sản xuất nông nghiệp tăng bình quân 3,8 - 4\%/năm; công nghiệp tăng bình quân $7,4 \%$ năm, trong đó sản xuất hàng tiêu dùng tăng 13 $14 \% /$ năm; giá trị kim ngạch xuất khẩu tăng $28 \% /$ năm.

- Giai đoạn 1991 - 1995: GDP bình quân tăng 8,2\%/năm; giá trị sản xuât công nghiệp tăng 13,3\%/năm; nông nghiệp tăng 4,5\%/năm; lĩnh vực dịch vụ tăng $12 \% /$ năm; tổng sản lượng lương thực 5 năm (1991 - 1995) đạt 125,4 triệu tấn, tăng 27\% so với giai đoạn 1986 - 1990.

- Giai đoạn 1996 - 2000: GDP bình quân đạt 7\%; trong đó, nông, lâm, ngư nghiệp tăng $4,1 \%$; công nghiệp và xây dựng tăng $10,5 \%$; các ngành dịch vụ tăng $5,2 \%$.

- Giai đoạn 2001 - 2005: GDP tăng bình quân 7,5\%/năm, riêng năm 2005 đạt 8,4\%; trong đó, nông nghiệp tăng 3,8\%; công nghiệp và xây dựng tăng $10,2 \%$; các ngành dịch vụ tăng $7 \%$.

- Giai đoạn 2006 - 2010: GDP bình quân 5 năm đạt 7\%.

- Giai đoạn 2011-2014: GDP bình quân ước đạt 5,67\% do ảnh hưởng chung của cuộc suy thoái kinh tế toàn cầu.

Về phát triển các mặt xã hội: năm 2014, GDP bình quân đầu người vượt mức 2000 USD/người/năm; từ năm 1991 đến nay hẳng năm giải quyết cho khoảng 1,4 triệu người lao động có việc làm; hoàn thành giảm một nửa tỷ lệ nghèo vào năm 2015 mà Mục tiêu Thiên niên kỷ (MDGs) của Liên hợp quốc đã đề ra; phát triển mới về quy mô, đa dạng hóa về loại hình trường lớp từ mầm non, tiểu học đến cao đẳng, đại học; bảo hiểm y tế được mở rộng đến khoảng gần $60 \%$ dân số, tuồi thọ trung bình của người dân từ 63 tuổi năm 1990 tăng lên 72 tuổi năm 2014 .
}

với chủ nghĩa xã hội, Đảng Cộng sản Việt Nam phải vận dụng sáng tạo những lý luận và phương pháp luận của chủ nghĩa Marx - Lenin một cách sáng tạo, phù hợp với thực tiễn, thậm chí phát triển chủ nghĩa Marx - Lenin cả về nhận thức lý luận lẫn kinh nghiệm thực tiễn. Thực tế lịch sử ở Liên Xô và nhiều nước xã hội chủ nghĩa khác từ sau chiến tranh thế giới thứ hai đã hoặc dần xa rời những nguyên lý cơ bản của chủ nghĩa Marx-Lenin, hoặc vận dụng một cách rập khuôn, máy móc, giáo điều, duy ý chí... đã dẫn đến những khủng hoảng kinh tế - xã hội không thể vượt qua được. Ở nước ta, những khủng hoảng kinh tế - xã hội khoảng thập kỷ đầu sau ngày thống nhất là biểu hiện và minh chứng cụ thể cho những những sai lầm khi vận dụng một cách giáo điều, rập khuôn, sơ cứng, thiếu sáng tạo mô hình xây dựng chủ nghĩa xã hội ở Liên Xô, vốn đã tồn tại nhiều khiếm khuyết, vi phạm nhiều nguyên tắc, quy luật của chủ nghĩa xã hội...Công cuộc đổi mới của Việt Nam thành công chắc chắn sẽ cung cấp nhiều kinh nghiệm, bài học cho quá trình xây dựng mô hình chủ nghĩa xã hội ở các nước nghèo ở Á, Phi, Mỹ la tinh,...

Thứ hai là bài học về tôn trọng quy luật khách quan, tránh rơi vào hai "căn bệnh": nóng vội, chủ quan, duy ý chí hoặc bảo thủ, trì trệ. Thực tiễn 30 năm đổi mới đã chỉ rõ, con đường duy nhất đưa đất nước thoát khỏi khủng hoảng chỉ có thể con đường đổi mới. Một trong những nguyên nhân và cũng là bài học được rút ra từ những khủng hoảng trì trệ này là trong một thời kỳ dài, những cương lĩnh, đường lối, chủ trương xây dựng đất nước đã không tôn trọng những quy luật khách quan của nền kinh tế, vi phạm nguyên lý cơ bản của cơ chế thị trường; chủ quan, áp đặt một nền kinh tế chỉ huy trong hoàn cảnh điểm xuất phát của nền kinh tế đất nước còn rất thấp... Do đó, những điều chỉnh trong tư duy như công nhận thành phần kinh tế tư nhân, mở rộng thị trường, cải cách cơ chế giá... đã ngay lập tức tác động tích cực đến nền kinh tế, tạo điều kiện để tất cả các thành phần kinh tế "bung" ra, hòa cùng dòng chảy của cơ chế thị trường. Bên cạnh đó, cũng dễ

\section{Trang 126}


nhận thấy, bước chuyển kinh tế của đất nước từ mô hình kinh tế kế hoạch bao cấp sang nền kinh tế thị trường định hướng xã hội chủ nghĩa đã được thực hiện một cách cẩn trọng, từng bước, không nóng vội, hấp tấp, nhưng cũng kiên quyết dẹp bỏ các biểu hiện bảo thủ, trì trệ, không để bỏ lỡ thời cơ. Những cú "sốc" ở Liên Xô, Đông Âu và phần nào đó ở Trung Quốc là những bài học đắt giá cho những bước chuyển nóng vội. Tuy vậy, tính "bùng nổ" của công cuộc đổi mới ở nước ta cũng được các nhà khoa học ghi nhận với những giải pháp mang tính đồng bộ, cấp tiếp, quyết liệt.

Thứ ba là bài học về mối quan hệ giữa thực tiễn - tu duy - chính sách. Thời gian khoảng 10 năm đầu sau ngày thống nhất là thời kỳ trì trệ, khủng hoảng kinh tế - xã hội của đất nước, nhưng cũng là giai đoạn chứng kiến những đột phá, cách làm hay, sáng tạo từ các địa phương... Những đột phá "từ dưới lên" đó trước hết tạo nên những chuyển biến tích cực trong chính địa phương, xí nghiệp, cơ quan đó; nhưng trên hết, nó tác động mạnh đến tư duy những nhà lãnh đạo, thuyết phục họ bằng hiệu quả thực tiễn. Và cũng từ đó, những điều chỉnh, chuyển hướng, loại bỏ cái cũ lạc hậu, kém hiệu quả "từ trên xuống” bằng cái mới tiến bộ, phù hợp thông qua các biện pháp, chủ trương, chính sách được ban hành. Thành công của công cuộc đổi mới của đất nước ta, ngoài nhân tố lãnh đạo, chỉ đạo của Đảng, điều hành của Nhà nước, còn có một phần đóng góp rất lớn chính từ những trăn trở, tìm tòi, đột phá, sáng tạo, dám nghĩ dám làm, của những cá nhân, người lao động tại các bộ phận, cơ quan, đơn vị, xí nghiệp... cấp cơ sở. Đó là quá trình kết hợp sự năng động, sáng tạo của quần chúng với sự nhạy bén, sâu sát của đội ngũ lãnh đạo. Do đó, bài học về "lấy dân làm gốc", sát dân, sát thực tiễn... luôn là bài học quý đối với những nhà lãnh đạo đất nước trong bất cứ thời kỳ nào.

Thư tu là bài học về kết hợp sức mạh nội lực của đất nuơóc với ngoại lự quốc tế. Một trong những chủ trương đúng đắn của Đảng và nhà nước, đồng thời cũng là thành tựu tựu quan trọng của công cuộc đổi mới là đất nước đã có những bước tiến dài trên con đường hội nhập quốc tế một cách chủ động và sâu rộng. Trong bối cảnh mà xu hướng toàn cầu hóa đang diễn ra một cách sôi động và mạnh mẽ như hiện nay, Việt Nam cần tận dụng tối đa những nguồn lực từ cộng đồng quốc tế, trước hết là tiếp thu những thành tựu khoa học kỹ thuật tiến bộ, những kinh nghiệm xây dựng và phát triển ở các nước phát triển, thu hút đầu tư và tranh thủ sự ủng hộ, giúp đỡ của cộng đồng quốc tế trong công cuộc xây dựng đất nước vì hòa bình, dân chủ và thịnh vượng. Thực tế lịch sử trong những năm qua đã chứng minh, công cuộc đổi mới của nước ta luôn gắn bó chặt chẽ với tiến trình hội nhập khu vực và thế giới; những cột mốc quan trọng đánh dấu quá trình hội nhập như bình thường hóa quan hệ với Trung Quốc, với Mỹ, gia nhập ASEAN hay trở thành thành viên của WTO... luôn có tác động mạnh mẽ đến tình hình kinh tế - chính trị của đất nước. Thực tế đó ngày càng khẳng định vai trò của hội nhập quốc tế và cũng đặt ra cho Việt Nam những đòi hỏi về một đường lối đối ngoại phù hợp, linh động và hiệu quả hơn trong giai đoạn sắp tới.

Cuối cùng là bài học về mối quan hệ giữa đổi mới kinh tế với đổi mới chính trị. Từ khi đổi mới đến nay, về quan điểm, Đảng đã chủ trương "Kết hợp ngay tù đầu đổi mói kinh tế với đổi mói chính trị, lấy đổi mới kinh tế làm trọng tâm, đồng thời tùng buớc đổi mới chính trị "30. Đây là nhận thức đúng cả về mặt lý luận cả về mặt thực tiễn. Khái niệm “đổi mới chính trị”" qua các văn kiện của Đảng được hiểu là đổi mới tư duy chính trị về chủ nghĩa xã hội; đổi mới cơ cấu tổ chức và cơ chế vận hành của hệ thống chính trị, trước hết là đổi mới phương thức lãnh đạo của Đảng; đổi mới, nâng cao hiệu quả quản lý của Nhà nước nhằm giữ vững ổn đinh chính trị để xây dựng chế độ xã hội chủ nghĩa ngày càng vững mạnh; thực hiện tốt nền dân chủ xã hội chủ nghĩa nhằm phát huy đầy đủ quyền làm chủ của nhân dân trong quá trình xây dựng nhà nước pháp

\footnotetext{
${ }^{30}$ Đảng Cộng sản Việt Nam (1996), Văn kiện Đai họi đại biểu toàn quốc lần thú VIII, NXB Chính trị Quốc gia, Hà Nội, tr.71.
} 
quyền xã hội chủ nghĩa và phát triển kinh tế - xã hội dưới sự lãnh đạo của Đảng. Đảng rất thận trọng trong đổi mới về chính trị. Một mặt không cho phép sự lợi dụng đổi mới để gây rối loạn, làm mất môi trường ổn định chính trị; mặt khác nhất quyết không chậm trễ trong đổi mới hệ thống chính trị, nhất là việc hoàn thiện hệ thống pháp luật, cải cách hành chính, công tác tổ chức - cán bộ, quan hệ của Đảng với Nhà nước và cá đoàn thể nhân dân. Đại hội XI của Đảng đã đưa ra quan điểm về mối quan hệ giữa đổi mới kinh tế với đổi mới chính trị: "Đổi mới chính trị phải đồng bộ với đổi mới kinh tế theo lộ trình thích hợp, trọng tâm là hoàn thiện thể chế kinh tế thị truờng xã hội chủ nghĩa, đổi mói phuoong thức lãnh đạo của Đảng, xây dụng Nhà nước pháp quyền xã hội chủ nghĩa, mở rộng dân chủ trong Đảng và trong xã hội gắn với tăng cuờng kỷ luật, kỷ cuong" ${ }^{31}$.

Sau ngày 30/4/1975, Việt Nam bước ra khỏi cuộc chiến với hành trang xây dựng đất nước là niềm hân hoan của ngày vui thống nhất. Từ đây, đất nước ta đứng trước những thời cơ, vận hội mới xen lẫn với những thử thách không nhỏ trong quá trình xây dựng và bảo vệ Tổ quốc: vừa đồng thời tiếp tục cầm súng bảo vệ biên giới lãnh thổ; vừa ra sức củng cố chính quyền thống nhất còn non trẻ, xây dựng và phát triển kinh tế - văn hóa - xã hội... Những diễn biến khó lường và phức tạp của đời sống quan hệ quốc tế những năm 1970-1980 đã có tác động xấu đến tình hình kinh tế - chính trị trong nước, đặc biệt là cuộc khủng hoảng ở hàng loạt các nước xã hội chủ nghĩa. Trong bối cảnh đó, để đưa đất nước thoát khỏi khủng hoảng, bảo vệ thành quả cách mạng vừa giành được, Đảng Cộng sản Việt Nam đã khởi xướng công cuộc đổi mới ở nước ta từ Đại hội Đảng toàn quốc lần thứ VI (1986) với trọng tâm là chuyển đổi nền kinh tế kế hoạch tập trung bao cấp sang nền kinh tế thị trường định hướng xã hội chủ nghĩa. Kể từ đó đến nay, nước ta đã từng bước ra khỏi khủng hoảng, ổn định đời sống kinh tế - xã hội, tăng tốc phát triển kinh tế, giữ vững an ninh quốc phòng, chủ động hội nhập quốc tế... Cùng với Trung Quốc, nước ta một trong số ít những nước xã hội chủ nghĩa đã thành công trong công cuộc đổi mới, cải cách, giữ vững được chế độ xã hội chủ nghĩa và có những bước phát triển đột phá về kinh tế. Bài học về con đường đổi mới ở Việt Nam sẽ còn được nhắc đến như là một trong những hình mẫu chuyển đổi mô hình kinh tế thành công nhất, để lại nhiều bài học quý báu và sâu sắc. 30 năm đổi mới là quãng thời gian Đảng, Nhà nước, cùng với toàn dân tộc đã ra sức tìm tòi, sáng tạo và đúc kêt, xây dựng thành một mô hình kinh tế - chính trị theo định hướng xã hội chủ nghĩa phù hợp với thực tiễn đất nước. Dĩ nhiên, còn rất nhiều thử thách đang chờ và rất nhiều những quy luật mới cần phải nắm bắt để tiếp tục thành công.

31 Đảng Cộng sản Việt Nam (2011), Văn kiện Đại hội đại biểu toàn quốc lần thư XI, Nxb Chính trị Quốc gia, Hà Nội, tr.99-100. 


\section{The process of formation and development of the economic innovation path in Vietnam (1986-2015)}

- Vo Van Sen

- Duong Thanh Thong

University of Social Sciences and Humanities, VNU-HCM

\section{ABSTRACT:}

The collapse of the socialist regimes in Soviet Union and Eastern European socialist countries in the late $20^{\text {th }}$ century was that of an inappropriate socialist model. In Vietnam after the unification of the nation, coping with the requirements posed by the socio-economic context of the country, the Communist Party of Vietnam worked out the leading path for the innovation mission in a comprehensive manner, which was firstly the economic innovation focusing on the transformation from the centrally planned economy into the socialist-oriented market economy; along with the "open-door" policy and the international integration policy. The foundation of the innovation was a process summed up from the reality of the then socio-economic life, from costly lessons from the socialist model as well as reforms and reshuffling in socialist countries. This paper presents the process of formation and development of ways of thinking, paths of economic innovation in Vietnam from the perspective of successes and lessons learned.

Keywords: innovation, Vietnam economy, Socialist

\section{TÀI LIẸU THAM KHẢO}

[1]. Adam Fforde - Stefan de Vylder (1997), Tù kế hoạch đến thị truờng: sư chuyển đổi kinh tế ở Việt Nam, NXB Chính trị Quốc gia, Hà Nội.

[2]. Anita Chan, Benedict J. Tria Kerkvliet, and Jonathan Unger (1999) Transforming Asian Socialism: China and Vietnam Compared, NXB Allen \&Unwin, NSW -Australian National University (Australia).

[3]. Börje Ljunggren (Chủ biên, 1994), Nhũng thách thức trên con đường cải cách ở Đông Duoong, NXB Chính trị Quốc gia, Hà Nội.
[4]. Phạm Minh Chính - Vương Quân Hoàng (2009), Kinh tế Việt Nam thăng trầm và đột phá, NXB Chính trị Quốc gia, Hà Nội.

[5]. Đảng Cộng sản Việt Nam (1987), Văn kiện Đại hội đại biểu toàn quốc lần thứ VI, NXB Sự thật, Hà Nội.

[6]. Đảng Cộng sản Việt Nam (1991),Văn kiện Đại hội đại biểu toàn quốc lần thư VII, NXB Sự thật, Hà Nội.

[7]. Đảng Cộng sản Việt Nam (1996), Văn kiện Đại hội đại biểu toàn quốc lần thứ VIII, NXB Chính trị quốc gia, Hà Nội. 
[8]. Đảng Cộng sản Việt Nam (2001), Văn kiện Đại hội đại biểu toàn quốc lần thư IX, NXB Chính trị quốc gia, Hà Nội.

[9]. Đảng Cộng sản Việt Nam (2004), Văn kiện Đảng toàn tập, NXB Chính trị Quốc gia, Hà Nội.

[10]. Đảng Cộng sản Việt Nam (2006), Văn kiện Đại hội đại biểu toàn quốc lần thứ $X, \mathrm{Nxb}$. Chính trị quốc gia, Hà Nội

[11]. Đảng Cộng sản Việt Nam (2011), Văn kiện Đại hội đại biểu toàn quốc lần thư XI, Nxb Chính trị Quốc Gia, Hà Nội.

[12]. Kornai János (1992), The Socialist System, NXB Princeton University, Princeton, New Jersey (USA).

[13]. Kornai János (2007), Con đường dẫn tới nền kinh tế tụ do, NXB Tri thức, Hà Nội.

[14]. V.I.Lênin (1978), Toàn tập (tập 36), NXB Tiến bộ, Moskva

[15]. Mác và Ăngnghen (1993), Toàn tập, tập 18, NXB Chính trị Quốc gia, Hà Nội.

[16]. Michel Beaud - Gilles Dostaler (2008), Tu tương kinh tế kể tù Keynes, NXB Tri thức, Hà Nội.

[17]. Nhà xuất bản Quân đội nhân dân (2003), Đảng Cộng sản Việt Nam với công cuộc đổi mới đất nước, NXB Quân đội Nhân dân, Hà Nội.
[18]. Nhiều tác giả (2006), Kỷ yếu hội thảo khoa học "Công cuộc đổi mới ở Việt Nam: những vấn đề khoa học và thực tiễn”, NXB Đại học Quốc gia TP. Hồ Chí Minh.

[19]. Đặng Phong (2009), Tu duy kinh tế Việt Nam 1975-1989, NXB Tri thức, Hà Nội.

[20]. Đặng Phong (2009), "Phá rào" trong kinh tế vào đêm trước đổi mới, NXB Tri thức, Hà Nội.

[21]. Đào Xuân Sâm - Vũ Quốc Tuấn (Chủ biên, 2008), Renovation in Vietnam: Recollection and Contemplation, NXB Tri thức, Hà Nội.

[22]. Randolph Barker (Chủ biên, 1993), Phân tích về chính sách nông nghiệp trong giai đoạn chuyển tiếp sang một nền kinh tế định hướng thị trường ở Việt Nam.

[23]. Trần Văn Thọ (2006), Biến động kinh tế Đông Á và con đường công nghiệp hóa Việt Nam, NXB Trẻ, TP. Hồ Chí Minh.

[24]. Ulrike Herrmann (2014), Tâu Âu trong tiến trình phát triển kinh tế. Con đường đưa thế giới đến thịnh vượng: lịch sử tiến trình xã hội, lịch sử tiền tệ và những cuộc khủng hoảng, NXB Tri thức, Hà Nội. 